\begin{tabular}{|c|c|}
\hline Proceeding of the $9^{\text {th }}$ ICEE Conference 3-5 April 2018 & CEA \\
Military Technical College \\
Kobry El-Kobbah, \\
Cairo, Egypt
\end{tabular}

\title{
CEA-3
}

\section{Exergetic Analysis of Flat-Plate Solar Collector used for Desalination by Humidification-dehumidification}

\author{
Wael Abdelmoez, Eman A. Ashour, Noha M.Sayed
}

\begin{abstract}
In the present work, exergy analysis of flat-plate solar collector is presented in details. Flat-plate solar collector is used for heating saline water, which is the first stage of water desalination process by humidification-dehumidification technique. This stage is considered as the most energy intensive stage. Accordingly, it is important to investigate its performance by using exergy analysis. The exergetic efficiency of solar heating system was examined in different ways to determine the most critical parameters that control the solar heating process. A comparison between both traditional energy (based on the first law of thermodynamics) and exergy analyses (based on the second law of thermodynamics) of a flat-plate solar heater type is carried out to show the importance of such exergy analysis and to show the limitations of conventional energy analysis. Exergy analysis gives a comprehensive and detailed behavior of solar heater performance under different conditions.
\end{abstract}

Keywords:-

Exergy, Exergy analysis, Desalination, Humidification-dehumidification

Department of Chemical Engineering, Faculty of Engineering, Minia University, 61516 Minia, Egypt

Tel. +20 100 0859791; Fax: +20 86 2346674; email: drengwael2003@yahoo.com 

Military Technical College
Kobry El-Kobbah, Cairo, Egypt

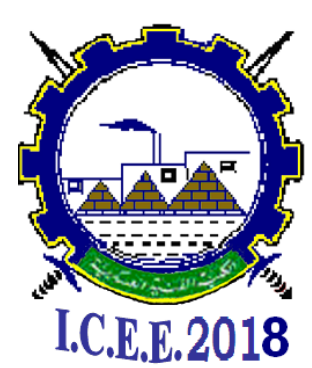

$9^{\text {th }}$ International Conference on

Chemical \& Environmental

Engineering

3-5 April 2018

\section{1- Introduction}

The increasing of energy demand with the limitation of the fossil fuel has led to search for an alternative renewable energy source such as solar energy. Solar energy is considered a clean, sustainable, and a high potentially in generating electricity source. Solar heating systems are used for converting solar energy into thermal or electrical energy. The main component of solar heating system is the solar collector. Solar collectors are similar to heat exchanger that converts solar radiation into heat. There are different types of collectors, among them flat-plate solar collector is representing one of the old as well as efficient one in hot countries. It has a simple construction and lower manufacturing cost. Solar collector performance is affected by the changes in design and operational parameters that is commonly analyzed by using a traditional energy analysis that is based on first law of thermodynamics (FLT) which represents the concept of energy conservation. However, energy efficiency cannot be considered an accurate measure of system performance as the deviation between actual and ideal efficiency is not provided. In addition, this analysis method is neglecting the environmental conditions and internal irreversibilities of the system. On the other hand, exergy analysis overcomes the limitations of traditional energy analysis. Exergy analysis is a thermodynamic technique based on second law of thermodynamics (SLT) which considered as a tool used for enhancing and optimizing designs and analyses. This analysis provides the deviation of actual performance of process and ideal one. It indicates the types, sources and locations of energy losses[1]. Exergetic and energetic analysis of flat-plate solar collector was carried out by Farzad et al [2]. They studied the effect of working fluid flow rate, fluid temperature, type of fluid, and back insulation thickness. Based on their results, the optimum inlet temperature was $40^{\circ} \mathrm{C}$. It was found that, overall collector efficiency improved by lowering fluid flow rate. Energetic and exergetic efficiencies were found to be $80 \%, 8 \%$ respectively. It was found that, water is the best working fluid. In winter, water -ethylene glycol is appropriate solution. It was found that, back insulation over $5 \mathrm{~cm}$ has no effect on energetic and exergetic efficiencies. Ebru et al [3] investigated the performance of flat-plate solar air heater with different obstacles and without obstacles. They compared between first and second law efficiencies. Results showed that, first law efficiency changed from $(20-82 \%)$ and second law efficiency varied from $(8.32-44 \%)$. It was found that, efficiency of the collector was enhanced by adding obstacles on absorber plate and by increasing airflow rate. S. Farahat et al [4] developed a simulation program to determine the thermal and exergetic efficiency of flatplate solar collector. Results of the program were agreed with the experimental measurements. The effect of various parameters was studied such as inlet fluid temperature, ambient temperature, optical efficiency, and solar intensity per unit area of 

Military Technical College
Kobry El-Kobbah, Cairo, Egypt

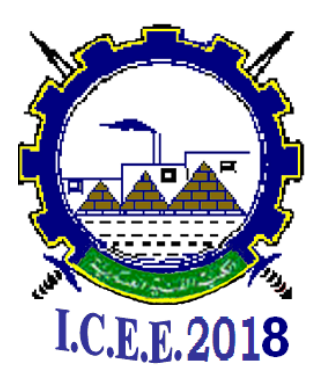

$9^{\text {th }}$ International Conference on

Chemical \& Environmental Engineering

3-5 April 2018

absorber plate. As the results showed, exergetic efficiency of solar collector increased with increasing incident solar radiation and inlet fluid temperature. However, exergetic efficiency decreased with increasing wind speed and ambient temperature. M.K. Gupta et al [5] evaluated energy and exergy output rates of flat-plate solar air heater with varying of length to width ratio of absorber plate, mass flow rate per unit area of plate, and duct depth. They aimed to evaluate the optimum design parameters that give maximum exergy output rate. It was found that, exergy output rate depended on entropy and heat gain. Deniz Alta et al[6] conducted an experimental investigation of three different types of flat-plate solar air heaters.

The second and third types having fins while the first without fins. In addition, first and second collector having double glass covers and the third have one glass cover. Energy and exergy output rates were determined with different airflow rates $(25,50$, and 100 $\left.\mathrm{m}^{3} / \mathrm{m}^{2} . \mathrm{h}\right)$ and tilt angles $\left(0^{\circ}, 15^{\circ}\right.$, and $\left.30^{\circ}\right)$. Based on the obtained results, solar heater with double glass covers and fins was more efficient than other types as temperature difference between inlet and outlet air was high.

A low airflow rate gave a good performance than high. Huseyin Benli et al[7] investigated experimentally the performance of five types of flat-plate solar air collectors. They presented exergy analysis of these types and efficiencies were calculated and compared. It was found that, solar collector efficiency improved with increasing airflow rate. In addition to, collector efficiency depended on the surface geometry of the collector. Sukruedee et at [8] carried out a comparison between exegetic efficiency of flat-plate and evacuated tube water heaters . They designed a storage tank with a five levels for the analysis. Temperature of water at each level is measured at each hour. Exergetic efficiency of each collector was calculated.

It was found that, exergetic efficiency of flat-plate and evacuated tube water heaters were $7.91 \%$ and $8.20 \%$ respectively. Koholé et al [9] developed a thermodynamic optimization based on exergy analysis for flat-plate solar water heater. In order to calculate the optimal design parameters that maximizes exergetic efficiency. It was found that, heater efficiency was improved by changing the distance between glass cover and absorber plate from 0.001 to $0.03 \mathrm{~m}$.

Exergetic efficiencies of flat-plate solar water heater were the same when the distance between glass cover and absorber plate was greater than $0.04 \mathrm{~m}$. Based on the obtained results, higher exergetic efficiency with lower absorber plate area may be reached. In the present work, a comparison between energy and exergy analysis of flat-plate solar water heater was carried out. Energy and exergy efficiencies are calculated with different saline water flow rates, ambient temperature, and inlet saline water temperature. 
Military Technical College

Kobry El-Kobbah,

Cairo, Egypt

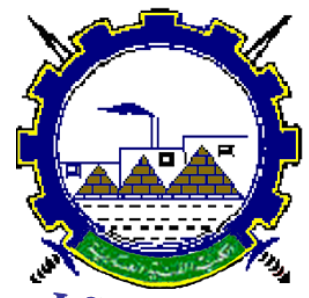

I.C.E.E.2018 $9^{\text {th }}$ International Conference on

Chemical \& Environmental

Engineering

3-5 April 2018

\section{Materials and Methods}

\subsection{Materials}

System consists of two main cycles; the first is the closed cycle where a mixture of water and ethylene glycol is heated in six identical flat-plate solar collectors. The second is an open cycle where saline water is heated by indirect contact with the mixture in a heat exchanger made from stainless steel 304. This innovative construction is designed to prevent corrosion of collector due to using saline water. Specifications of the whole system are summarized in table (1).

\subsection{Methods}

Different parameters are measured such as inlet and outlet water-ethylene glycol mixture temperatures, inlet and outlet saline water temperatures, and mean plate temperature using thermocouple (K-type) connected with temperature meter as shown in fig (1). The incident solar intensity is measured using solar power meter. The experiment is repeated for three days (22, 23, and 24 August 2017).

\section{Theoretical Analysis}

The energy analysis was carried out for both main components of the solar heating system. These are solar collectors and the heat exchanger inside the storage tank. Both traditional as well as exergy analyses were calculated separately and the obtained results in each case were compared.

\subsection{Traditional Energy Analysis}

The traditional energy analysis is based mainly on the first law of thermodynamic and its mathematical definitions and meaning.

\subsubsection{Flat-Plate Solar Collector}

Considering a steady state condition, the energy balance equation indicates that, useful energy output of flat-plate solar collector equal to the difference between the absorbed solar energy by the collector and thermal losses.

$$
\begin{aligned}
& Q_{g}=A_{c} I_{T} \\
& Q_{l}=A_{c} U_{L}\left(T_{p m}-T_{a}\right)
\end{aligned}
$$


Military Technical College

Kobry El-Kobbah,

Cairo, Egypt

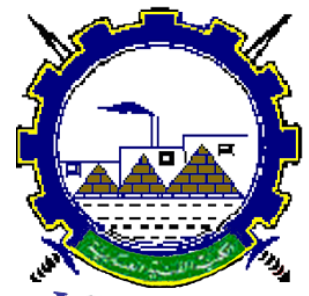

I.C.E.E.2018 $9^{\text {th }}$ International Conference on

Chemical \& Environmental

Engineering

3-5 April 2018

$$
\begin{aligned}
& Q_{u}=Q_{g}-Q_{l} \\
& Q_{u}=A_{c}\left(S-U_{L}\left(T_{p m}-T_{a}\right)\right)
\end{aligned}
$$

Where:- $S=(\tau \boldsymbol{\alpha}) I_{T}$

It is important to define the heat removal factor $F_{R}$ that is the ratio between the actual useful energy gain if the whole collector surface is at the inlet fluid temperature and the useful energy gain.

$$
F_{R}=\frac{\dot{m} c_{p}\left(T_{f o}-T_{f i}\right)}{A_{c}\left(s-U_{L}\left(T_{f i}-T_{a}\right)\right)}
$$

So, the maximum possible useful energy equal to the actual energy gain.

$$
Q_{u}=A_{c} F_{R}\left(S-U_{L}\left(T_{f i}-T_{a}\right)\right)
$$

$\mathrm{U}_{\mathrm{L}}$ is the overall heat loss coefficient, which is the sum of the top heat loss coefficient $\mathrm{U}_{\mathrm{t}}$, bottom heat loss coefficient $\mathrm{U}_{\mathrm{b}}$, and edge heat loss coefficient $\mathrm{U}_{\mathrm{e}}$.

$$
\begin{aligned}
U_{L} & =\mathrm{U}_{t}+U_{b}+U_{a} \\
\mathrm{U}_{t} & =\left(\left(\frac{N}{\frac{C}{T_{p m}}\left[\frac{\left[T_{p m}-T_{a j}\right.}{(N)+f)}\right]^{\varepsilon}}+\frac{1}{h_{w}}\right)\right)^{-1}+\frac{\sigma\left(T_{p m}+T_{a}\right)\left(T_{p m}{ }^{2}+T_{a}^{2}\right)}{\frac{1}{\varepsilon_{p}+0.00591 N h_{w}}+\frac{2 N+f-1+0.18 s}{\varepsilon_{g}}-N} \\
f & =\left(1+0.089 h_{w}-0.1166 h_{w} \varepsilon_{p}\right)(1+0.07866 N) \\
C & =520\left(1-0.000051 \mathrm{~B}^{2}\right) \\
e & =0.430\left(1-\frac{100}{T_{p m}}\right) \\
h_{w} & =5.7+3.8 V_{R} \\
U_{b} & =\frac{K}{L} \\
U e & =\frac{k_{l} A_{g}}{L_{\varepsilon} A_{p}}
\end{aligned}
$$

First law efficiency of the collector is defined as the ratio between the actual heat gain to the incident solar energy.[12] 
Military Technical College

Kobry El-Kobbah, Cairo, Egypt

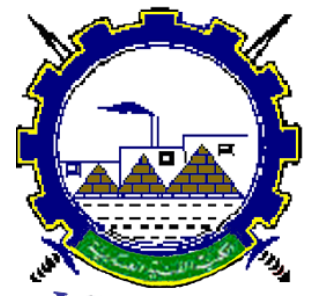

I.C.E.E.2018 $9^{\text {th }}$ International Conference on

Chemical \& Environmental

Engineering

3-5 April 2018

$$
\eta_{\mathrm{I}}=\frac{Q_{u}}{I_{T} A_{c}}
$$

\subsubsection{Heat Exchanger}

Useful energy absorbed by the fluid:-

$$
Q_{u, h}=\dot{m} C_{p}\left(T_{f, o}-T_{f, i}\right)
$$

First law efficiency of the heat exchanger:-

$$
\eta_{\mathrm{I}}=\frac{Q_{u_{n}}}{Q_{u}}
$$

Overall energetic efficiency of the solar heating system:-

$$
\eta_{\mathrm{I}}=\frac{Q_{\mathrm{u} h}}{I_{T} A_{e}}
$$

\section{Exergy analysis}

Exergy analysis is based mainly on the second law of thermodynamic and its mathematical definitions and meaning.

\section{Flat-Plate Solar Collector}

General exergy balance equation can be written in the following form

$$
E_{\text {in }}-E_{s}-E_{\text {out }}-E_{d}=0
$$

At steady state conditions $E_{s}=0$

$$
E_{d}=E_{\text {in }}-E_{\text {out }}
$$

The inlet exergy rate is the sum of inlet exergy carried by the fluid and exergy radiation from the sun.

The inlet exergy rate carried by the fluid is expressed as:-

$$
E_{i n, f}=\dot{m} C_{p}\left(T_{f i}-T_{a}-T_{a} \ln \left(\frac{T_{f i}}{T_{a}}\right)\right)
$$

The exergy radiation from the sun:-

$$
E_{i n, Q}=I_{T} A_{c}\left(1-\frac{T_{a}}{T_{s}}\right)
$$

The exergy rate outlet carried by fluid flow:- 
Military Technical College Kobry El-Kobbah, Cairo, Egypt

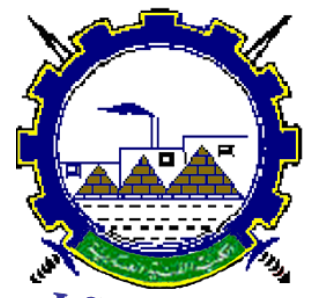

I.C.E.E.2018 $9^{\text {th }}$ International Conference on

Chemical \& Environmental

Engineering

3-5 April 2018

$$
E_{\text {out }, f}=\dot{m} C_{p}\left(T_{f o}-T_{\alpha}-T_{\alpha} \ln \left(\frac{T_{f o}}{T_{a}}\right)\right)
$$

Exergy analysis allows calculating exergy losses due to heat loss from the absorber plate to the environment, exergy destruction due to temperature difference between the sun and absorber plate, exergy destruction due to radiation losses from the collector surface to the absorber plate, and exergy destruction due to the temperature difference between the fluid and absorber plate[11].

Exergy destruction rate due to heat loss from the absorber plate to the environment:-

$$
E_{d, 1}=U_{L} A_{p}\left(T_{p m}-T_{a}\right)\left(1-\frac{T_{a}}{T_{p m}}\right)
$$

Exergy destruction rate due to temperature difference between the sun and absorber plate:-

$$
E_{d, 2}=(\tau \boldsymbol{\alpha}) I_{T} A_{p} T_{a}\left(\frac{1}{T_{p m}}-\frac{1}{T_{s}}\right)
$$

Exergy destruction rate due to radiation losses from the collector surface to the absorber plate:-

$$
E_{d, 3}=I_{T}\left[A_{c}-(\tau \boldsymbol{\alpha}) A_{p}\right]\left(1-\frac{T_{a}}{T_{s}}\right)
$$

Exergy destruction rate due to the temperature difference between the fluid and absorber plate:-

$$
E_{d, 4}=\dot{m} C_{p} T_{a}\left[\ln \left(\frac{T_{f, 0}}{T_{f, i}}\right)-\frac{\left(T_{f, 0}-T_{f, i}\right)}{T_{p m}}\right]
$$

Useful exergy rate can be calculated from the following equation:-

$$
E_{\text {u }}=E_{\text {out }, f}-E_{\text {in } f}
$$

Flat-plate solar collector efficiency is the ratio between useful exergy rate and solar radiation exergy rate (second law efficiency)[11]:-

$$
\eta_{e x}=\frac{E_{\text {out }, f}-E_{\text {in }, f}}{I_{T} A_{e}\left(1-\frac{T_{a}}{T_{s}}\right)}
$$

\subsubsection{Heat Exchanger}

Useful exergy delivered by saline water is:-

$$
\begin{aligned}
& E_{u, h}=\dot{m}\left(E_{\circ}-E_{i}\right)[13] \\
& E_{u, h}=\dot{m}\left(\left(H_{f \circ}-H_{f i}\right)-T_{o}\left(S_{f \circ}-S_{f i}\right)\right) \\
& \left(H_{f \circ}-H_{f i}\right)=C_{p}\left(T_{f \circ}-T_{f i}\right)
\end{aligned}
$$


Military Technical College

Kobry El-Kobbah,

Cairo, Egypt

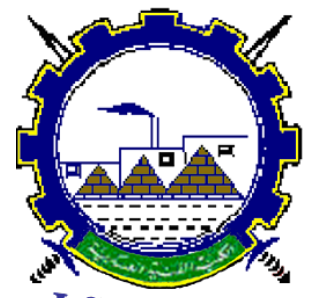

I.C.E.E.2018 $9^{\text {th }}$ International Conference

on

Chemical \& Environmental

Engineering

3-5 April 2018

$$
\begin{aligned}
& \left(s_{f \circ}-s_{f i}\right)=C_{p} \ln \left(\frac{T}{T_{0}}\right)[14] \\
& E_{u, h}=\dot{m} C_{p}\left(\left(T_{f o}-T_{f i}\right)-T_{o} \ln \left(\frac{T_{f o}}{T_{f i}}\right)\right)[15]
\end{aligned}
$$

Useful exergy can be calculated directly from the equation:-

$$
E_{f, \text { out }}-E_{f, i n}=\dot{m} C_{p}\left(\left(T_{f o}-T_{f i}\right)-T_{a}\left(\ln \left(\frac{T_{f o}}{T_{f i}}\right)\right)\right.
$$

Second law efficiency of heat exchanger:-

$$
\eta_{e x}=\frac{E_{\text {fuot }}-E_{f_{\text {in }}}}{E_{u}}=\frac{E_{u, h}}{E_{u}}[16]
$$

Overall exergetic efficiency of the solar heating system:-

$$
\eta=\frac{E_{u_{\text {, h }}}}{E_{Q_{\text {in }}}}
$$

\section{Results and discussions}

\subsection{Experimental evaluation of theoretical analysis}

Energy and exergy analyses, which discussed in section (2) have been evaluated experimentally. All experiments were carried out on August 2017. Table 1 shows the specifications of tested flat-plate collectors. The working fluid in the collectors is a mixture of water and ethylene glycol (4\%). Fig .4 shows a photograph of experimental set-up.

Solar intensity, ambient temperature, mean plate temperature, inlet and outlet mixture temperature, inlet, and outlet saline water temperature were measured in different three days with different saline water flow rate $(0.05,0.03,0.067 \mathrm{~kg} / \mathrm{s})$.

\subsubsection{Flat-plate Solar collector}

Figure (6) shows the variation of the incident solar intensity with time in three different days. The incident solar intensity is measured each half hour from 8 am to $6 \mathrm{pm}$ in different three days. The obtained results indicated that the solar intensity is almost the similar in the three different days.

Fig (7) shows the relation between the measured mean-plate temperatures with time in three different days. It was found that, the highest mean-plate temperature recorded at 2 pm in all days. In addition, day (2) has the highest mean-plate temperature. 


\section{Military Technical College \\ Kobry El-Kobbah, Cairo, Egypt}

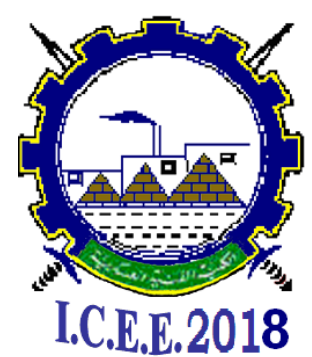

9ํㅡㄴ International Conference on

Chemical \& Environmental Engineering

3-5 April 2018

Fig (8) shows the variation of outlet water-ethylene glycol mixture temperature with time in three days in solar collector. Based on the obtained results, day (2) has the highest outlet water-ethylene glycol mixture temperature.

All collected data were summarized in table (3). The data in the table were used to calculate overall heat loss coefficient using equations from 8 to 15 .

Fig (9) shows the relation between overall heat loss coefficients with time in three days. Day (1) has the highest the overall heat loss coefficient. It was found that; overall heat loss coefficient was almost constant in each day.

Energetic efficiency of solar collector is calculated by using traditional energy analysis from equation 1 to 16. Traditional energy analysis is not a detailed and accurate tool for analyzing thermal systems. As energetic efficiency of solar collector is not function of inlet and outlet mixture temperature. Fig (10) indicates that, energetic efficiency of solar collector almost the same in three days. However, there is a big difference in outlet mixture temperature between day (2) and the two other days.

Energy analysis does not give the qualitative assessment of various losses occurring in system components. So, exergy analysis is used to give a clear picture of various losses quantitatively as well as qualitatively. Exergetic efficiency of flat-plate solar collector was calculated by using equations (20,21, 22, 23, 24, 29, and 30). Results indicate that, exergetic efficiency of solar collector is found to be very small at the beginning and end of day. Due to low difference between inlet and outlet temperature of water-ethylene glycol mixture. It is found that; second day has the highest exergetic efficiency at $2 \mathrm{pm}$ $(11.33 \%)$ and a highest outlet mixture temperature. Fig (11) shows a negative value of exergetic efficiency at the end of the second day. As from 3.5 to $6 \mathrm{pm}$, inlet mixture temperature is greater than outlet mixture temperature in solar collectors. That gives a negative value of useful exergy as well as exergetic efficiency. This result explains that, the mixture inside the heat exchanger is not goodly mixed. In addition, at the end of the day solar intensity decreased and heat loss increased .Therefore, outlet temperature is decreased.

Exergy analysis allows calculating exergy destruction due to various causes as represented in section (2) from equations 25 to 28 . Exergy destructions occurring in solar collector is calculated for different three days. Table (7) represents the calculated exergy destruction in the second day and the other days with same configurations.

Based on results, it is found that the largest exergy destruction is $\mathrm{E}_{\mathrm{d} 2}$ due to a high difference between the sun and absorber plate temperature.

$\mathrm{E}_{\mathrm{d} 2}$ can be reduced by increasing inlet mixture temperature as shown in fig(12). 


\section{Military Technical College \\ Kobry El-Kobbah, Cairo, Egypt}

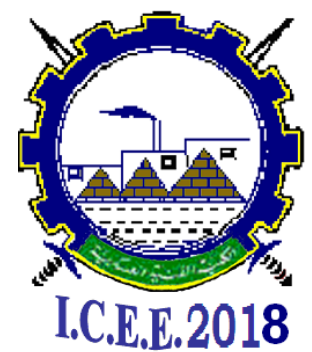

9ํㅡㄴ International Conference on

Chemical \& Environmental Engineering

3-5 April 2018

\subsubsection{Heat Exchanger}

Inlet and outlet saline water temperature is measured in different three days with different saline water flow rates. Fig (13) indicates that, day (2) has the highest saline water outlet temperature $\left(74.5^{\circ} \mathrm{C}\right)$ at $2 \mathrm{pm}$ at $0.03 \mathrm{~kg} / \mathrm{s}$.

Table 3 represents the values of the different measured temperatures and solar intensity in three different days for both solar collector and heat exchanger. Utilizing these data and using equation 1 to 38 , both energy and exergy efficiencies were calculated for the solar collectors and the heat exchanger.

As results shown, day (2) has the highest outlet water-ethylene glycol mixture temperature, highest exergetic efficiency, and highest outlet saline water temperature . So, a comparison between exergetic and energetic efficiency of solar collectors is carried out to describe the difference between them. Accumulated input and output energy were calculated using measured data and equations for second day with a saline water flow rate $0.03 \mathrm{~kg} / \mathrm{s}$ as shown in table (4).

Table (5) shows the accumulated input and output exergy for solar heating system at a saline water flow rate of $0.03 \mathrm{~kg} / \mathrm{s}$. Table (6) shows the comparison between energy and exergy analysis.

Fig.14 indicates that, exergetic efficiency of flat- plate solar collector is very low in comparison with energetic efficiency. The obtained results come with agreement with that previously reported by Farzad et al [2] reported that ,exergetic efficiency of flatplate solar collector is very low and need significant improvements. Fig (15) shows a comparison between energetic and exergetic efficiencies for solar heating system. It was found that, exergetic efficiency of solar heating system is very low comparing with energetic efficiency. Due to the degradation of exergy content of solar heat from high quality 95\% exergy content to a low exergy content (10-15)\%.[13]. Energy analysis shows that ,energetic efficiency of the system is very high in the second day. However ,exergy analysis indicates a lower quality of this energy. This is the difference between exergy and energy analysis. Energy analysis gives the quantity of energy regardless its qualtiy. But exergy analysis calculates the quality of energy as well as quantity.

\section{Conclusions:}

In the present work,energy and exergy analyses of solar heating system were carried out. Exergy analysis gives a comprehensive and detailed behaviour of collector performance under different conditions. It allows to define and calculate different causes and types of exergy destruction. 


\section{Military Technical College \\ Kobry El-Kobbah, Cairo, Egypt}

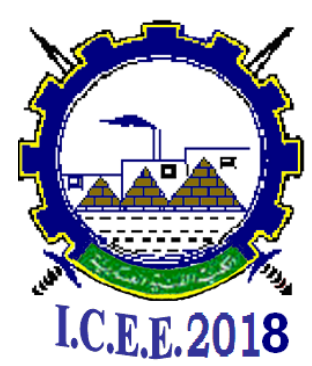

$9^{\text {th }}$ International Conference on

Chemical \& Environmental

Engineering

3-5 April 2018

According to energy analysis, it was found that:-

Energy analysis is not considered a good tool for analyzing thermal systems .

Energy analysis can not give the causes and locations where energy degradation occurs other than the loss of energy from plate to the environment.

Energetic efficiency of flat-plate solar collector is not function of inlet and outlet working fluid temperture.So, it is not give an accurate indication about the actual performance of the collector.

Based on exergy analysis ,it was found that:-

The largest part of exergy destruction is due to difference between plate and sun temperature which can be decreased by increasing inlet saline water temperature. It is recommended that, a good mixing of mixture inside the heat exchanger. Exergetic efficiency is increased by decreasing saline water flow rate.

\section{References}

[1] I. Dincer, T.A.H.R., Importance of exergy for analysis,improvement, design, and assessment. WIREs Energy and Environment, 2013. 2: p. 335-349.

[2] Farzad Jafarkazemi, E.A., Energetic and exergetic evaluation of flat plate solar collectors. Renewable Energy, 2013. 56: p. 55-63.

[3] Ebru Kavak Akpinar , F.K., Energy and exergy analysis of a new flat-plate solar air heater having different obstacles on absorber plates. Applied Energy,2010. 87: p. $3438-3450$.

[4] S. Farahat, F.S., H. Ajam, Exergetic optimization of flat plate solar collectors. Renewable Energy ,2009. 34: p. 1169-1174.

[5] M.K. Gupta , S.C.K., Exergetic performance evaluation and parametric studies of solar air heater. Energy ,2008. 33: p. 1691- 1702.

[6] Deniz Alta , E.B., C. Ertekin, Osman Yaldiz Experimental investigation of three different solar air heaters: Energy and exergy analyses. Applied Energy, 2010. 87: p. 2953-2973.

[7] Benli, H., Experimentally derived efficiency and exergy analysis of a new solar air heater having different surface shapes. Renewable Energy ,2013. 50: p. 58-67.

[8] Sukruedee Sukchai, Y.M.a.W.W., Comparative Analysis of Exergy and Efficiency for Stratified Thermal Storage Tank with Solar Flat Plate and Evacuated Tube Collectors. Applied Mechanics and Materials, 2016. 855: p. 114-118. 
Military Technical College Kobry El-Kobbah, Cairo, Egypt

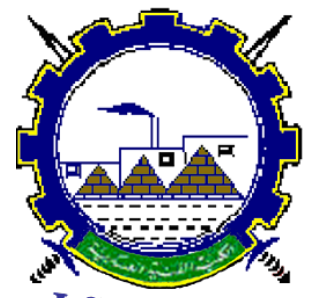

I.C.E.E.2018 $9^{\text {th }}$ International Conference on

Chemical \& Environmental Engineering

3-5 April 2018

[9] Ghislain, K.Y.W.a.T., Optimization of flat-plate solar collectors used in thermosyphon solar water heater. International Journal of Renewable Energy Technology Research ,2017. 6: p. 1-23.

[10] A. Ucar, M.I., Thermal and exergy analysis of solar air collectors with passive augmentation techniques. International Communications in Heat and Mass Transfer ,2006. 33: p. 1281-1290.

[11] Zhong Ge, H.W., Hua Wang, Songyuan Zhang and Xin Guan . Exergy Analysis of Flat Plate Solar Collectors. Entropy, 2014. 16: p. 2549-2567.

[12] John A. Duffie, W.A.B., Solar Engineering of Thermal Processes. John Wiley \& Sons, Inc., 2013.

[13] Narendra Singh, S.C.K., R.D. Misra, Exergetic analysis of a solar thermal power system. Renewable Energy ,2000. 19: p. 135-143.

[14] Boles, Y.A.Ç.a.M.A., Thermodynamics: An Engineering Approach. McGraw-Hill, 2006. 5th ed.

[15] K Gnana Sundari, V.P.a.T.M.N.K., Exergy Analysis of A low Temperature Thermal Desalination System. Int. J. Mech. Eng. \& Rob. Res., 2013. 2: p. 284-289.

[16] Suha Orçun Mert, A.R., Experimental performance investigation of a shell and tube heat exchanger by exergy based sensitivity analysis. Heat Mass Transfer, 2016. 52: p. 1117-1123.

\section{Acknowledgement}

The Misr El Kheir Foundation is gratefully acknowledged for the support of this work under scientific grant agreement between Misr El Kheir foundation and Minia University-Faculty of Engineering. 
Military Technical College

Kobry El-Kobbah, Cairo, Egypt

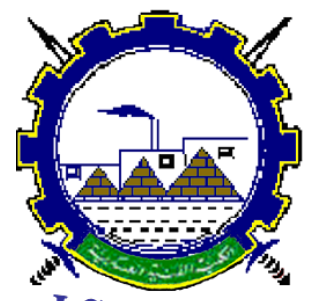

I.C.E.E.2018 $9^{\text {th }}$ International Conference on

Chemical \& Environmental

Engineering

3-5 April 2018

\section{Nomenclature}

$I_{T} \quad$ Solar radiation intensity $\left(\mathrm{W} / \mathrm{m}^{2}\right)$

$V_{R} \quad$ Wind velocity $(\mathrm{m} / \mathrm{s})$

A Area $\left(\mathrm{m}^{2}\right)$

$\mathrm{C}_{\mathrm{p}} \quad$ Specific heat capacity (kj/kg.k)

E Exergy rate $(\mathrm{kj} / \mathrm{s})$

$\mathrm{H} \quad$ Specific enthalpy $(\mathrm{kj} / \mathrm{kg})$.

$\mathrm{h}_{\mathrm{w}} \quad$ Wind heat transfer coefficient $\left(\mathrm{W} / \mathrm{m}^{2} . \mathrm{K}\right)$

K Thermal conductivity (W/m.K)

$\mathrm{L}$ Thickness of insulation(m)

$\mathrm{N} \quad$ Number of glass covers

P Pressure (kpa).

Q Heat transfer rate $(\mathrm{kj} / \mathrm{s})$

S Solar absorbed flux $\left(\mathrm{W} / \mathrm{m}^{2}\right)$.

s $\quad$ Specific entropy $(\mathrm{kj} / \mathrm{kg} . \mathrm{K})$,

$\mathrm{U}_{\mathrm{b}} \quad$ Bottom heat loss coefficient $\left(\mathrm{W} / \mathrm{m}^{2} . \mathrm{K}\right)$.

$\mathrm{U}_{\mathrm{e}} \quad$ Edge heat loss coefficient $\left(\mathrm{W} / \mathrm{m}^{2} . \mathrm{K}\right)$.

$\mathrm{U}_{\mathrm{L}} \quad$ Collector overall heat loss coefficient $\left(\mathrm{W} / \mathrm{m}^{2} . \mathrm{K}\right)$.

$\mathrm{U}_{\mathrm{t}} \quad$ Top heat loss coefficient $\left(\mathrm{W} / \mathrm{m}^{2} . \mathrm{K}\right)$.

\section{Subscripts}

fi Fluid inlet

fo Fluid outlet

u Useful ambient

pm Plate mean

c Collector

p Plate

S Sun

d Destruction

ex Exergy

I Energy

g Glass, gain

o Dead state

e Side

u Useful

L Loss

D Day

\section{Greek symbols}

$\tau$ Transmittance

$\boldsymbol{\alpha}$ Absorptance

$\eta \quad$ Efficiency

$\varepsilon$ Emittance 


\begin{tabular}{|l|c|}
\hline Proceeding of the $9^{\text {th }}$ ICEE Conference 3-5 April 2018 & CEA \\
Military Technical College \\
Kobry El-Kobbah, \\
Cairo, Egypt
\end{tabular}

Table 1: Specifications of flat-plate solar collector

\begin{tabular}{lc}
\hline Parameter & Value \\
\hline Collector area & $2 \mathrm{~m}^{2}$ \\
Number of cells & 6 \\
Absorber plate area & $1.89 \mathrm{~m}^{2}$ \\
Optical efficiency & 0.86 \\
Emissivity of absorber plate & 0.26 \\
Absorptance of absorber plate & 0.94 \\
Thickness of insulation & $50 \mathrm{~mm}$ \\
Thickness of collector & $90 \mathrm{~mm}$ \\
Thickness of glass cover & $4 \mathrm{~mm}$ \\
Thermal conductivity of insulation & $0.04 \mathrm{w} / \mathrm{m} . \mathrm{K}$ \\
Diameter of copper tubes & $8 \mathrm{~mm}$ \\
Diameter of header tubes & $18 \mathrm{~mm}$ \\
Number of tubes & 9 \\
Collector tilt & $35^{\circ}$ \\
& \\
\hline
\end{tabular}

Table 2: Specifications of Heat Exchanger.

\begin{tabular}{lc}
\hline Parameter & Value \\
\hline Capacity & 300 lit/day \\
Heat Exchanger working pressure & $2-5 \mathrm{bar}$ \\
Maximum Temperature & $95{ }^{0} \mathrm{C}$ \\
Insulation Thickness (polyurethane) & $50 \mathrm{~mm}\left(40 \mathrm{~kg} / \mathrm{m}^{3}\right)$ \\
Thermal losses & $2 \mathrm{~W} / \mathrm{K}$ \\
Material of construction & Stainless Steel \\
Inner Cylinder Dimensions & $1340 \mathrm{~mm} * 480 \mathrm{~mm}$ \\
Boiler Inner Diameter & $446 \mathrm{~mm}$ \\
Boiler Inner Length & $1675 \mathrm{~mm}$ \\
Outer Cylinder Material & Electrostatic Powder Painted Steel \\
\hline
\end{tabular}


Military Technical College Kobry El-Kobbah, Cairo, Egypt

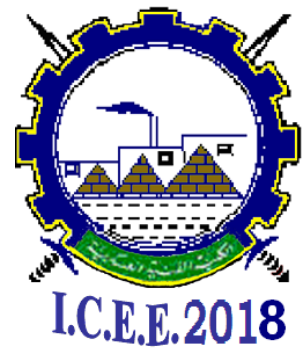

$9^{\text {th }}$ International Conference on Chemical \& Environmental Engineering 3-5 April 2018

Table 3. The values of the different measured temperatures and solar intensity in three different days for both solar collector and heat exchanger

\begin{tabular}{|c|c|c|c|c|c|c|c|c|c|c|c|c|c|c|c|c|c|c|c|c|c|}
\hline \multirow{3}{*}{$\begin{array}{c}\mathbf{T} \\
{[\mathbf{s}]}\end{array}$} & \multicolumn{6}{|c|}{ Solar Collector } & \multicolumn{6}{|c|}{ Heat Exchanger } & & & & & & & & & \\
\hline & \multicolumn{3}{|c|}{$\mathbf{T}_{\text {in }}$} & \multicolumn{3}{|c|}{$\mathbf{T}_{\text {out }}$} & \multicolumn{3}{|c|}{$\mathbf{T}_{\text {in }}$} & \multicolumn{3}{|c|}{$\mathbf{T}_{\text {out }}$} & \multicolumn{3}{|c|}{$\mathbf{T}_{\mathbf{a}}$} & \multicolumn{3}{|c|}{$\mathbf{T}_{\mathbf{p m}}$} & \multicolumn{3}{|c|}{$I_{T}$} \\
\hline & $\mathbf{D}_{1}$ & $\mathbf{D}_{2}$ & $\mathbf{D}_{3}$ & $\mathbf{D}_{1}$ & $\mathbf{D}_{2}$ & $\mathbf{D}_{3}$ & $\mathbf{D}_{1}$ & $\mathrm{D}_{2}$ & $\mathbf{D}_{3}$ & $\mathbf{D}_{1}$ & $\mathbf{D}_{2}$ & D3 & $\mathbf{D}_{1}$ & $\mathrm{D}_{2}$ & $\mathbf{D}_{3}$ & $\mathbf{D}_{1}$ & $D_{2}$ & $\mathbf{D}_{3}$ & $\mathbf{D}_{1}$ & $\mathbf{D}_{2}$ & $\mathbf{D}_{3}$ \\
\hline 8 & 41 & 31 & 43 & 64 & 34 & 54 & 29 & 29 & 28 & 66 & 31 & 60 & 27 & 26 & 27 & 46 & 37 & 51 & 1890 & 2018 & 1885 \\
\hline 8.5 & 43 & 35 & 48 & 52 & 37 & 51 & 31 & 29 & 29 & 51 & 37 & 52 & 28 & 27 & 27 & 57 & 42 & 55 & 1918 & 1898 & 1765 \\
\hline 9 & 51 & 40 & 45 & 51 & 44 & 48 & 30 & 30 & 30 & 45 & 35 & 48 & 32 & 31 & 30 & 58 & 51 & 52 & 1880 & 1766 & 1645 \\
\hline 9.5 & 53 & 47 & 44 & 51 & 51 & 49 & 31 & 30 & 31 & 45 & 37 & 47 & 34 & 33 & 32 & 70 & 64 & 64 & 1824 & 1640 & 1525 \\
\hline 10 & 58 & 56 & 46 & 52 & 60 & 51 & 33 & 31 & 32 & 46 & 56 & 49 & 34 & 38 & 33 & 73 & 73 & 67 & 1648 & 1514 & 1405 \\
\hline 10.5 & 60 & 61 & 48 & 54 & 66 & 54 & 33 & 32 & 32 & 48 & 58 & 51 & 35 & 40 & 34 & 75 & 78 & 70 & 1432 & 1419 & 1325 \\
\hline 11 & 63 & 67 & 49 & 56 & 73 & 56 & 34 & 33 & 33 & 50 & 62 & 52 & 35 & 40 & 35 & 78 & 85 & 71 & 1287 & 1323 & 1245 \\
\hline 11.5 & 65 & 72 & 51 & 58 & 79 & 57 & 34 & 33 & 33 & 51 & 67 & 53 & 36 & 40 & 35 & 80 & 89 & 73 & 1024 & 1233 & 1073 \\
\hline 12 & 65 & 76 & 51 & 58 & 82 & 58 & 33 & 35 & 33 & 52 & 71 & 55 & 35 & 40 & 36 & 80 & 92 & 74 & 785 & 1142 & 901 \\
\hline 12.5 & 64 & 79 & 52 & 58 & 85 & 59 & 34 & 35 & 34 & 60 & 74 & 55 & 35 & 40 & 37 & 79 & 94 & 74 & 519 & 973 & 693 \\
\hline 1 & 63 & 82 & 52 & 57 & 87 & 58 & 34 & 36 & 33 & 60 & 75 & 55 & 36 & 40 & 37 & 78 & 95 & 73 & 493 & 805 & 485 \\
\hline 1.5 & 62 & 84 & 51 & 57 & 89 & 57 & 34 & 36 & 34 & 60 & 75 & 54 & 37 & 40 & 37 & 75 & 95 & 72 & 484 & 593 & 490 \\
\hline 2 & 60 & 85 & 50 & 56 & 89 & 55 & 33 & 36 & 34 & 58 & 74 & 52 & 36 & 40 & 38 & 73 & 93 & 68 & 409 & 381 & 495 \\
\hline 2.5 & 58 & 84 & 49 & 55 & 88 & 52 & 34 & 36 & 34 & 56 & 74 & 51 & 37 & 40 & 37 & 70 & 91 & 65 & 402 & 369 & 448 \\
\hline 3 & 55 & 82 & 47 & 53 & 82 & 50 & 34 & 36 & 34 & 54 & 74 & 49 & 37 & 40 & 37 & 66 & 88 & 61 & 334 & 358 & 401 \\
\hline 3.5 & 52 & 78 & 45 & 50 & 72 & 46 & 35 & 37 & 34 & 52 & 71 & 47 & 38 & 41 & 37 & 60 & 82 & 56 & 294 & 322 & 347 \\
\hline 4 & 48 & 71 & 43 & 48 & 55 & 43 & 35 & 36 & 33 & 49 & 67 & 44 & 37 & 40 & 38 & 55 & 74 & 51 & 235 & 287 & 294 \\
\hline 4.5 & 43 & 62 & 41 & 45 & 51 & 41 & 34 & 36 & 33 & 46 & 65 & 42 & 39 & 37 & 36 & 48 & 60 & 47 & 180 & 255 & 239 \\
\hline 5 & 37 & 58 & 39 & 42 & 46 & 34 & 34 & 36 & 33 & 43 & 63 & 39 & 37 & 35 & 35 & 46 & 50 & 43 & 138 & 152 & 184 \\
\hline 5.5 & 34 & 54 & 37 & 40 & 45 & 32 & 33 & 35 & 33 & 41 & 61 & 37 & 35 & 35 & 34 & 43 & 44 & 41 & 66 & 97 & 113 \\
\hline 6 & 32 & 50 & 36 & 38 & 44 & 31 & 33 & 34 & 32 & 39 & 60 & 33 & 34 & 34 & 36 & 39 & 39 & 38 & 33 & 41 & 41 \\
\hline
\end{tabular}


Military Technical College Kobry El-Kobbah, Cairo, Egypt

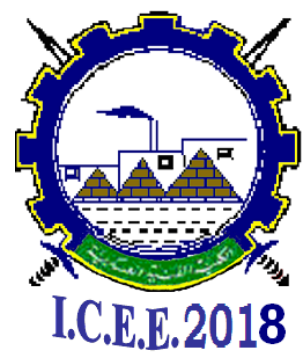

$9^{\text {th }}$ International Conference on

Chemical \& Environmental

Engineering

3-5 April 2018

Table 4. Energy analysis of solar heating system.

\begin{tabular}{|c|c|c|c|c|c|}
\hline System & $\begin{array}{c}\text { Energy } \\
\text { received(kw) }\end{array}$ & $\begin{array}{c}\text { Energy } \\
\text { delivered(kw) }\end{array}$ & $\begin{array}{c}\text { Energy loss } \\
(\mathrm{kw})\end{array}$ & $\begin{array}{c}\text { Energy } \\
\text { loss(\%) }\end{array}$ & $\begin{array}{c}\text { First law } \\
\text { efficiency(\%) }\end{array}$ \\
\hline $\begin{array}{c}\text { solar } \\
\text { collector }\end{array}$ & $215.59 \pm 4.93$ & $170.49 \pm 4.19$ & 45.09 & 20.92 & 79.08 \\
\hline $\begin{array}{c}\text { Heat } \\
\text { exchanger }\end{array}$ & $170.49 \pm 4.18$ & $90.04 \pm 5.63$ & 80.46 & 47.19 & 52.81 \\
\hline $\begin{array}{c}\text { Overall } \\
\text { system }\end{array}$ & $215.59 \pm 4.93$ & $90.03 \pm 5.63$ & 125.55 & 58.24 & 41.76 \\
\hline
\end{tabular}

Table 5.Exergy analysis of solar heating system.

\begin{tabular}{|c|c|c|c|c|c|}
\hline System & $\begin{array}{c}\text { Exergy } \\
\text { received (kw) }\end{array}$ & $\begin{array}{c}\text { Exergy } \\
\text { delivered(kw) }\end{array}$ & $\begin{array}{c}\text { Exergy } \\
\text { loss(kw) }\end{array}$ & $\begin{array}{c}\text { Exergy } \\
\text { loss(\%) }\end{array}$ & $\begin{array}{c}\text { Second law } \\
\text { efficiency }(\%)\end{array}$ \\
\hline $\begin{array}{c}\text { solar } \\
\text { collector }\end{array}$ & $196.68 \pm 4.67$ & $4.31 \pm 0.45$ & 192.38 & 97.81 & 2.19 \\
\hline $\begin{array}{c}\text { Heat } \\
\text { exchanger }\end{array}$ & $4.21 \pm 0.48$ & $2.35 \pm 0.15$ & 1.859981 & 44.21 & 55.79 \\
\hline $\begin{array}{c}\text { Overall } \\
\text { system }\end{array}$ & $196.69 \pm 4.67$ & $2.35 \pm 0.15$ & 194.34 & 98.81 & 1.19 \\
\hline
\end{tabular}

Table 6.Comparison between first and second law analysis of solar heating system.

\begin{tabular}{|c|c|c|c|c|}
\hline System & $\begin{array}{c}\text { Energy loss } \\
(\%)\end{array}$ & $\begin{array}{c}\text { Exergy loss } \\
(\%)\end{array}$ & $\begin{array}{c}\text { First law } \\
\text { efficiency }(\%)\end{array}$ & $\begin{array}{c}\text { Second law } \\
\text { efficiency(\%) }\end{array}$ \\
\hline $\begin{array}{c}\text { Solar } \\
\text { collector }\end{array}$ & 20.92 & 97.81 & 79.08 & 2.19 \\
\hline $\begin{array}{c}\text { Heat } \\
\text { exchanger }\end{array}$ & 47.19 & 44.21 & 52.81 & 55.79 \\
\hline $\begin{array}{c}\text { Overall } \\
\text { system }\end{array}$ & 58.24 & 98.81 & 41.76 & 1.19 \\
\hline
\end{tabular}


Military Technical College Kobry El-Kobbah, Cairo, Egypt

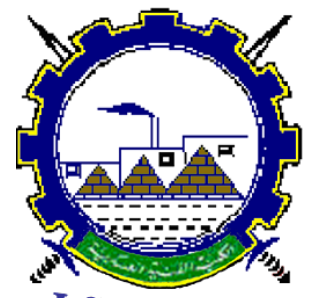

I.C.E.E.2018 $9^{\text {th }}$ International Conference on

Chemical \& Environmental

Engineering

3-5 April 2018

Table (7):- Exergy destruction in solar collector due to various causes.

\begin{tabular}{|c|c|c|c|c|}
\hline Time $(\mathrm{hr})$ & $\mathrm{E}_{\mathrm{d} 1}(\mathrm{w})$ & $\mathrm{E}_{\mathrm{d} 2}(\mathrm{w})$ & $\mathrm{E}_{\mathrm{d} d}(\mathrm{w})$ & $\mathrm{E}_{\mathrm{d} 4}(\mathrm{w})$ \\
\hline 8 & 7.731084 & 16534.03 & 3955.978 & 0.038877 \\
\hline 8.3 & 15.43786 & 16513.07 & 4013.594 & 0.033971 \\
\hline 9 & 19.49722 & 14946.03 & 3691.87 & 0.089257 \\
\hline 9.3 & 44.43138 & 13380.38 & 3426.768 & 0.137547 \\
\hline 10 & 54.66677 & 12204.43 & 3159.581 & 0.159654 \\
\hline 10.3 & 63.67916 & 11326.67 & 2958.815 & 0.177522 \\
\hline 11 & 84.14934 & 10364.85 & 2759.614 & 0.199412 \\
\hline 11.3 & 99.83743 & 9530.835 & 2570.842 & 0.206493 \\
\hline 12 & 109.9032 & 8762.297 & 2382.071 & 0.153798 \\
\hline 12.3 & 118.757 & 7419.382 & 2030.288 & 0.135942 \\
\hline 13 & 123.7153 & 6111.995 & 1678.505 & 0.117255 \\
\hline 13.5 & 123.2987 & 4503.873 & 1236.507 & 0.08916 \\
\hline 14 & 115.0979 & 2911.22 & 794.5102 & 0.052778 \\
\hline 14.5 & 107.1506 & 2839.118 & 770.2098 & 0.03597 \\
\hline 15 & 95.3384 & 2775.33 & 745.9093 & 0.003605 \\
\hline 15.5 & 72.44469 & 2551.727 & 672.1114 & -0.09568 \\
\hline 16 & 50.73346 & 2323.296 & 598.6465 & -0.3999 \\
\hline 16.5 & 23.35058 & 2141.211 & 532.0849 & -0.07603 \\
\hline 17 & 11.01344 & 1310.288 & 317.8635 & 0.052363 \\
\hline 17.5 & 4.016798 & 850.9674 & 202.1629 & 0.121905 \\
\hline 18 & 1.132293 & 369.4222 & 86.48362 & 0.134759 \\
\hline
\end{tabular}




\begin{tabular}{|c|c|}
\hline Proceeding of the $9^{\text {th }}$ ICEE Conference 3-5 April 2018 & CEA \\
$\begin{array}{c}\text { Military Technical College } \\
\text { Kobry El-Kobbah, } \\
\text { Cairo, Egypt }\end{array}$ & $\begin{array}{c}\text { Chemical \& Environmental } \\
\text { Engineering }\end{array}$ \\
\hline \hline
\end{tabular}
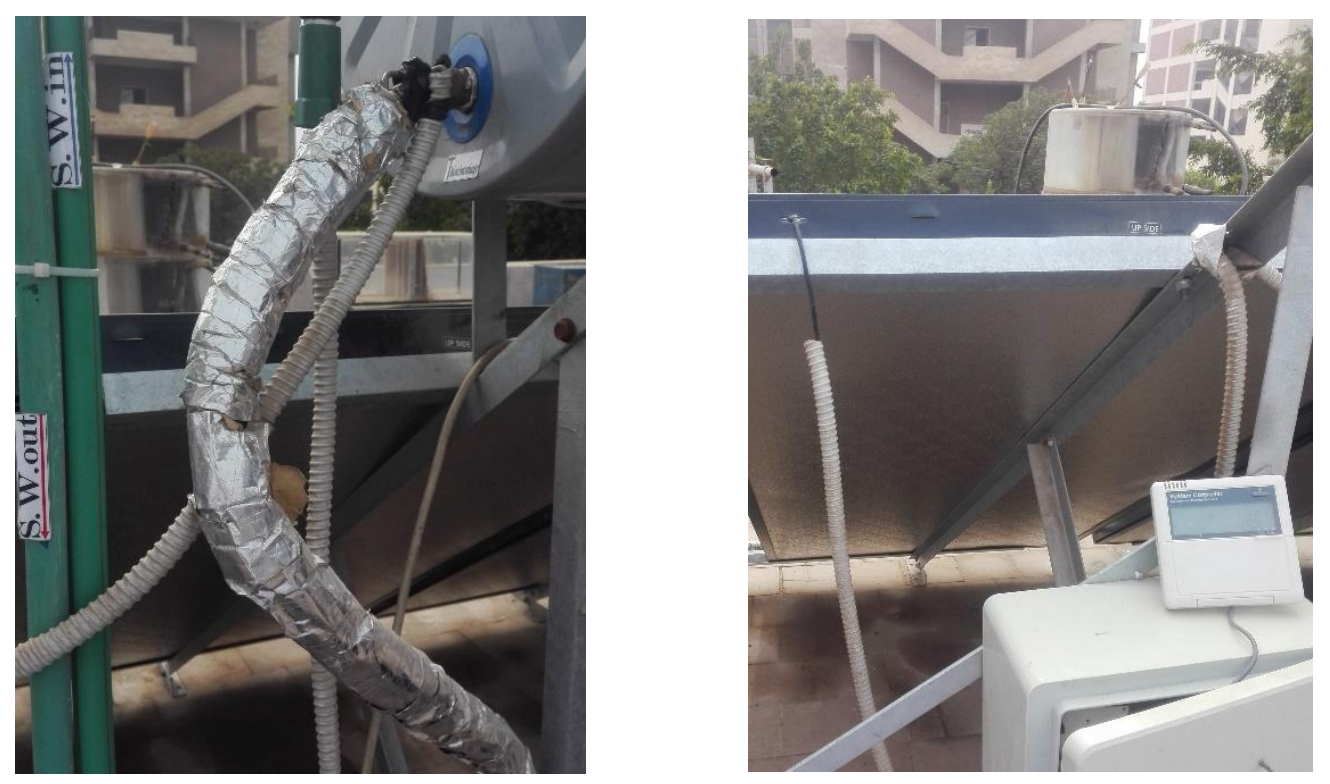

Fig.(1) Thermocouples Connections.
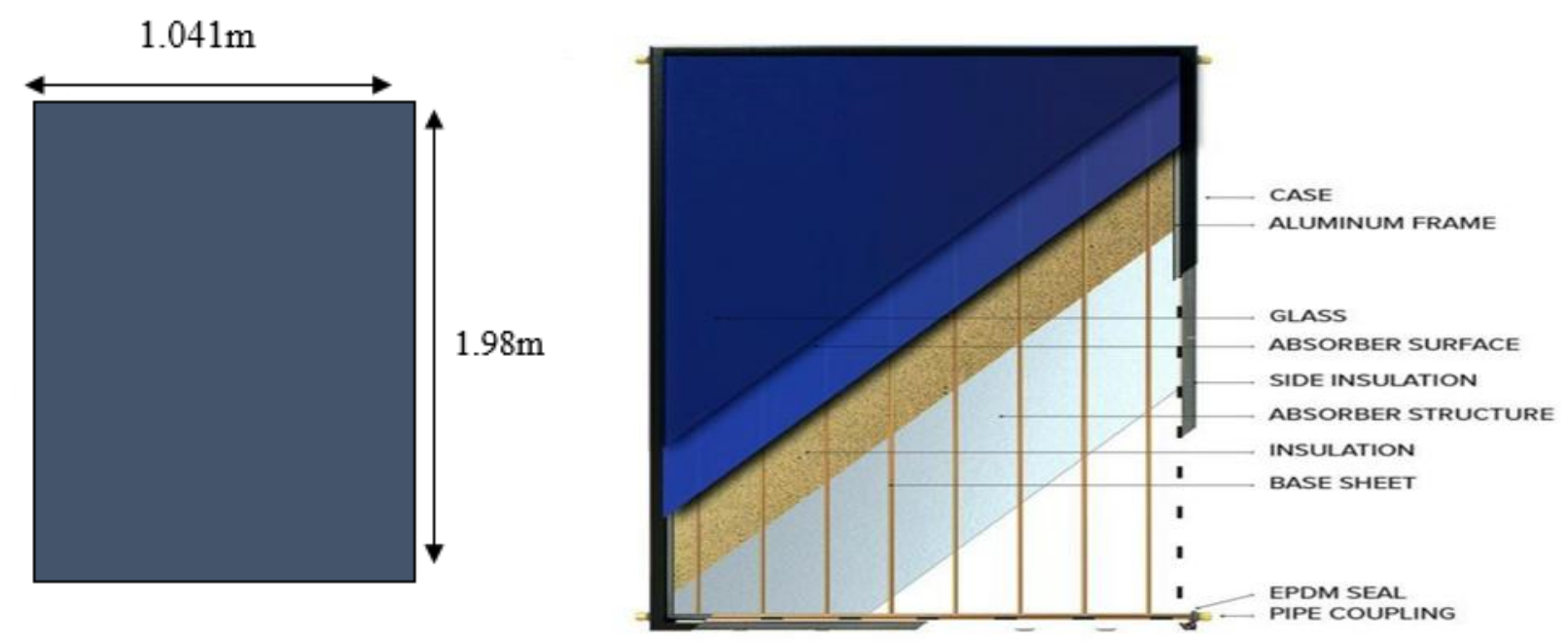

Fig. (2) Solar Collector Components 


\begin{tabular}{|c|c|}
\hline Proceeding of the $9^{\text {th }}$ ICEE Conference 3-5 April 2018 & CEA \\
Military Technical College \\
Kobry El-Kobbah, \\
Cairo, Egypt
\end{tabular}

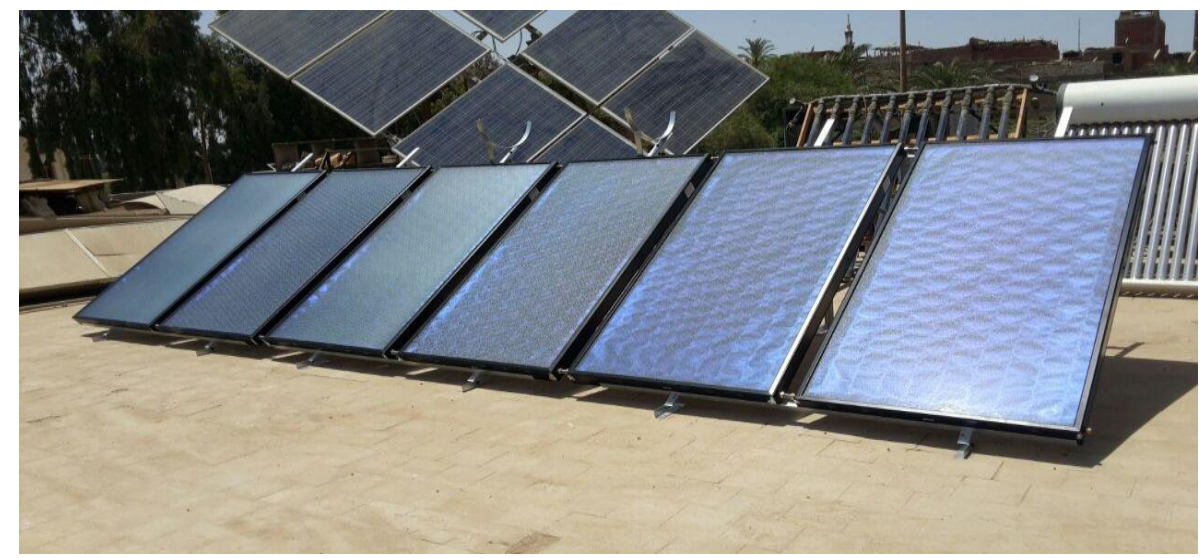

Fig. (3) Flat-plate solar collectors
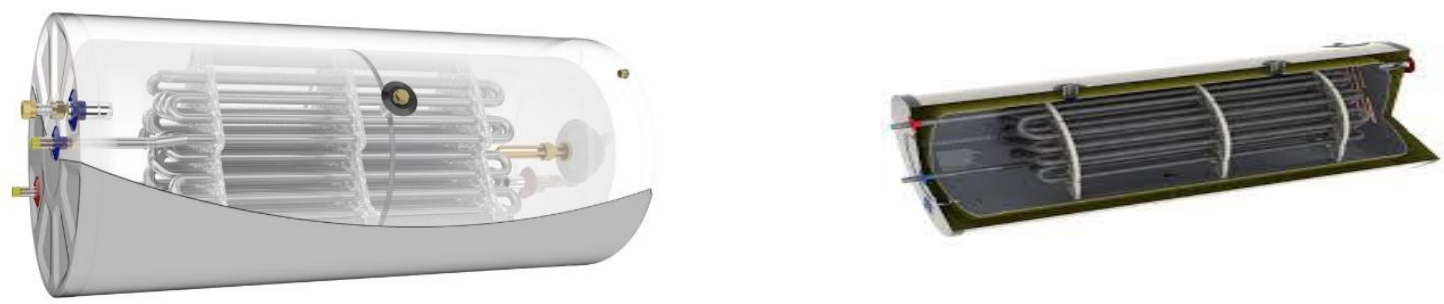

Fig. (4) Schematic representation of the Heat Exchanger inside the hot storage tank

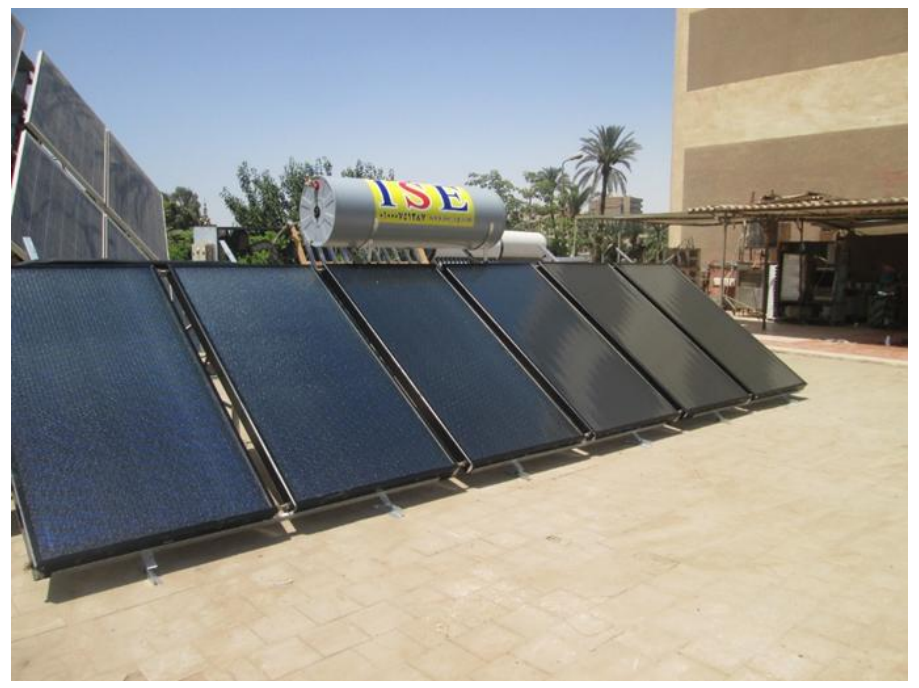

Fig. (5) Experimental Set-up 
Military Technical College

Kobry El-Kobbah,

Cairo, Egypt

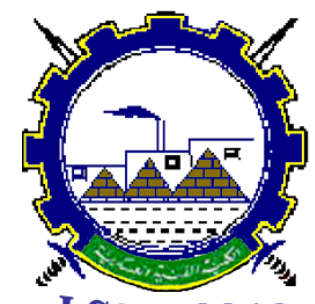

I.C.E.E.2018 $9^{\text {th }}$ International Conference on

Chemical \& Environmental

Engineering

3-5 April 2018

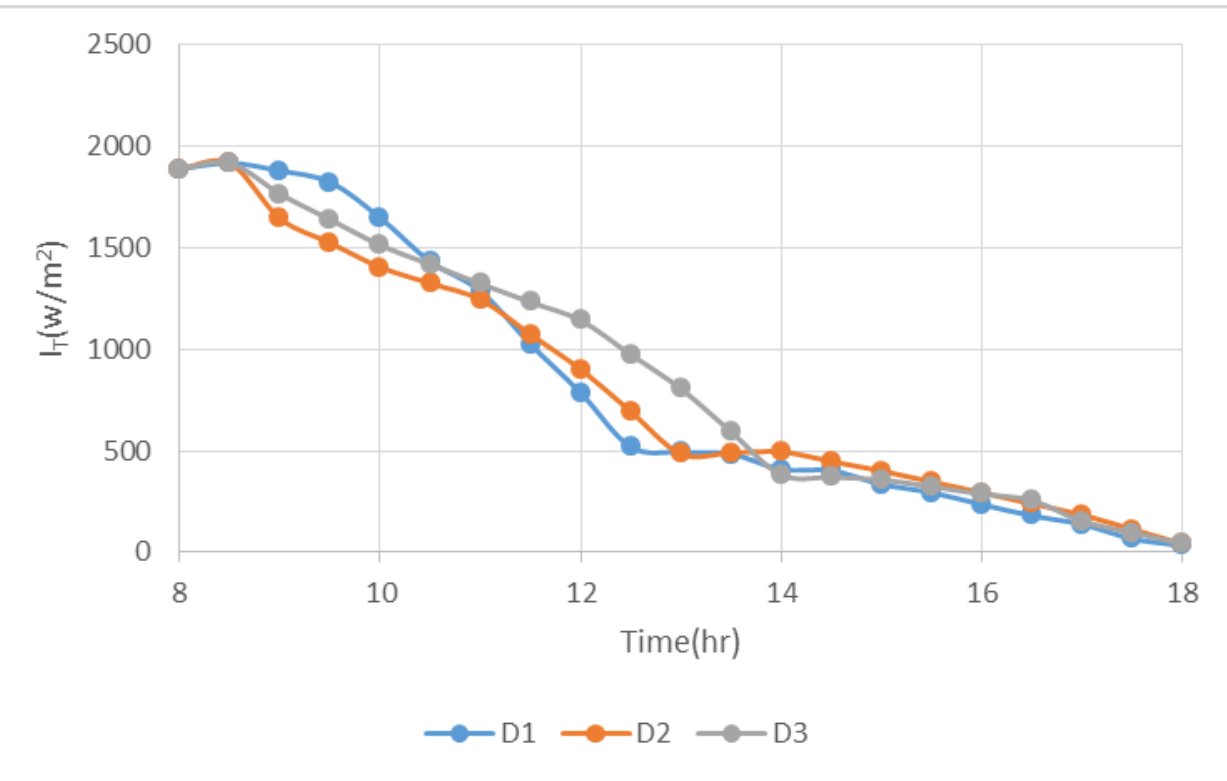

Fig. (6) Variation of incident solar intensity with time in three days

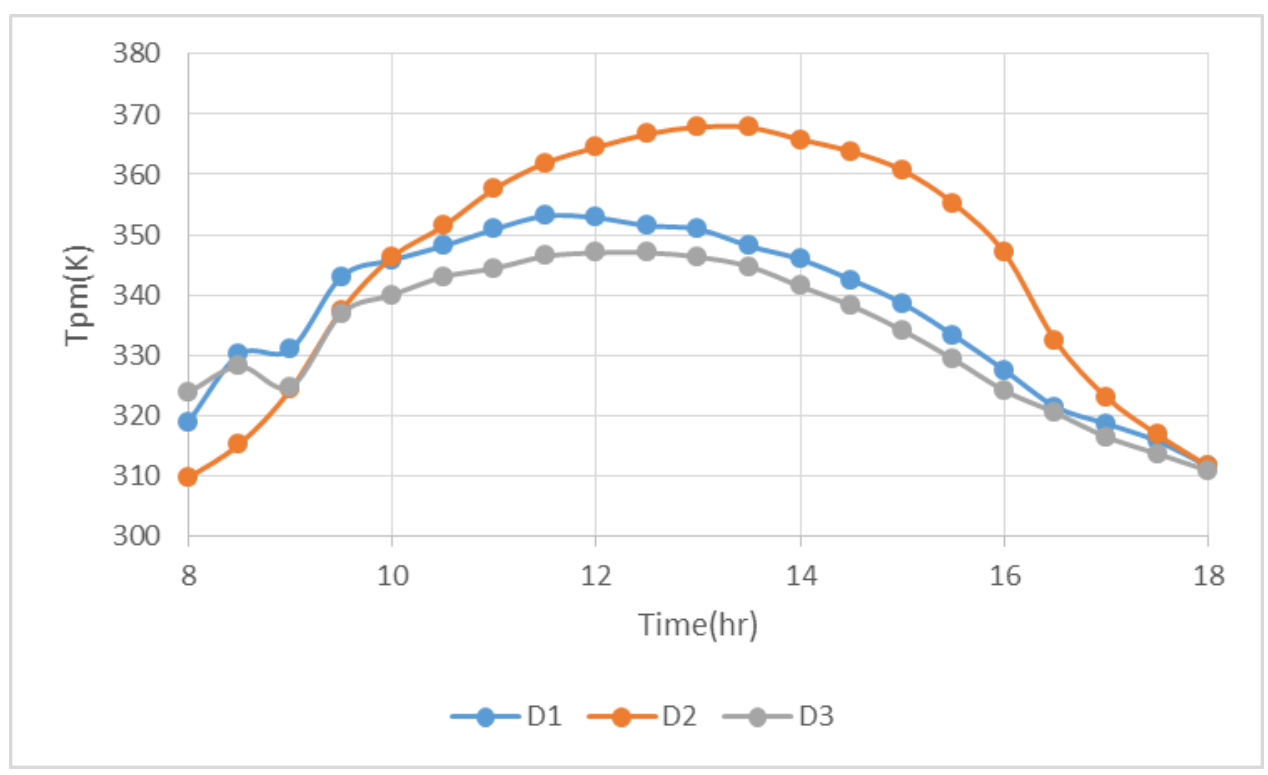

Fig.(7) Variation of mean-plate temperature with time in three days in solar collector 
Military Technical College Kobry El-Kobbah, Cairo, Egypt

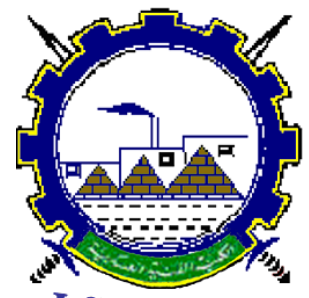

I.C.E.E.2018 $9^{\text {th }}$ International Conference on

Chemical \& Environmental

Engineering

3-5 April 2018

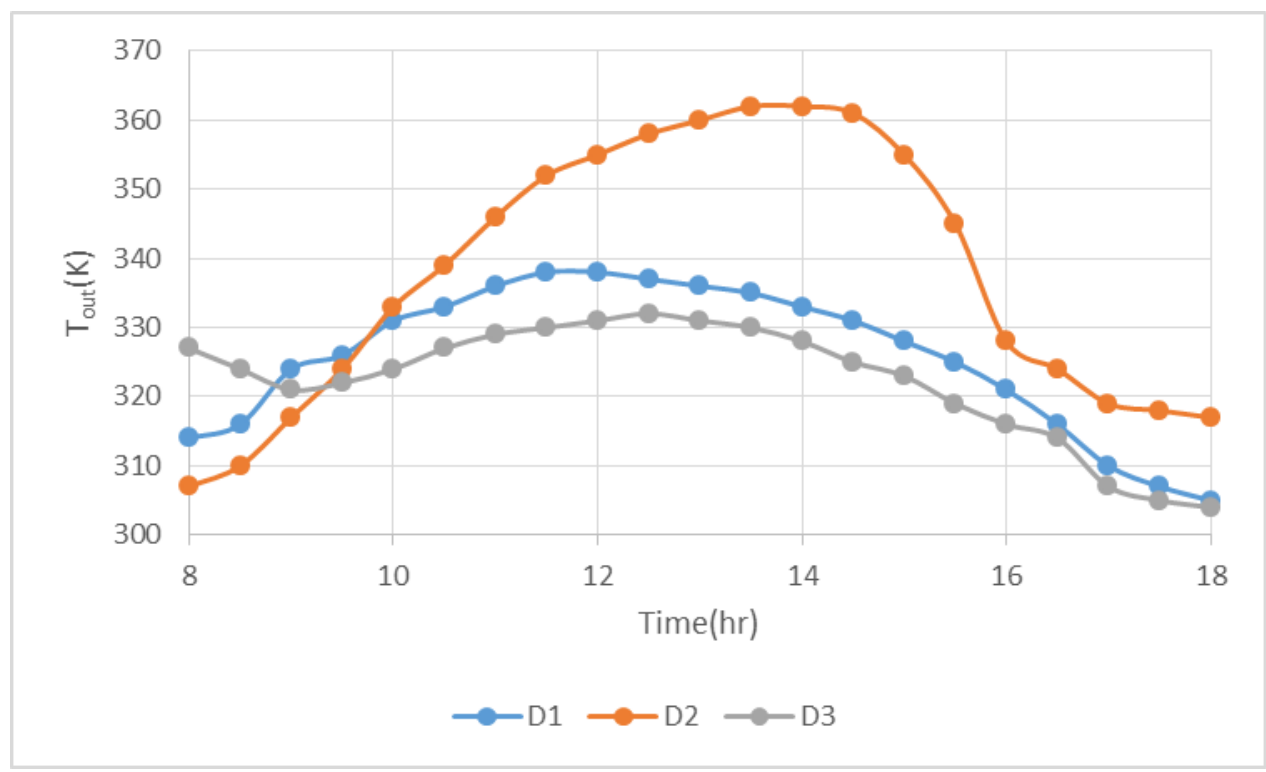

Fig. (8) Variation of outlet water-ethylene glycol mixture temperature with time in three days in solar collector.

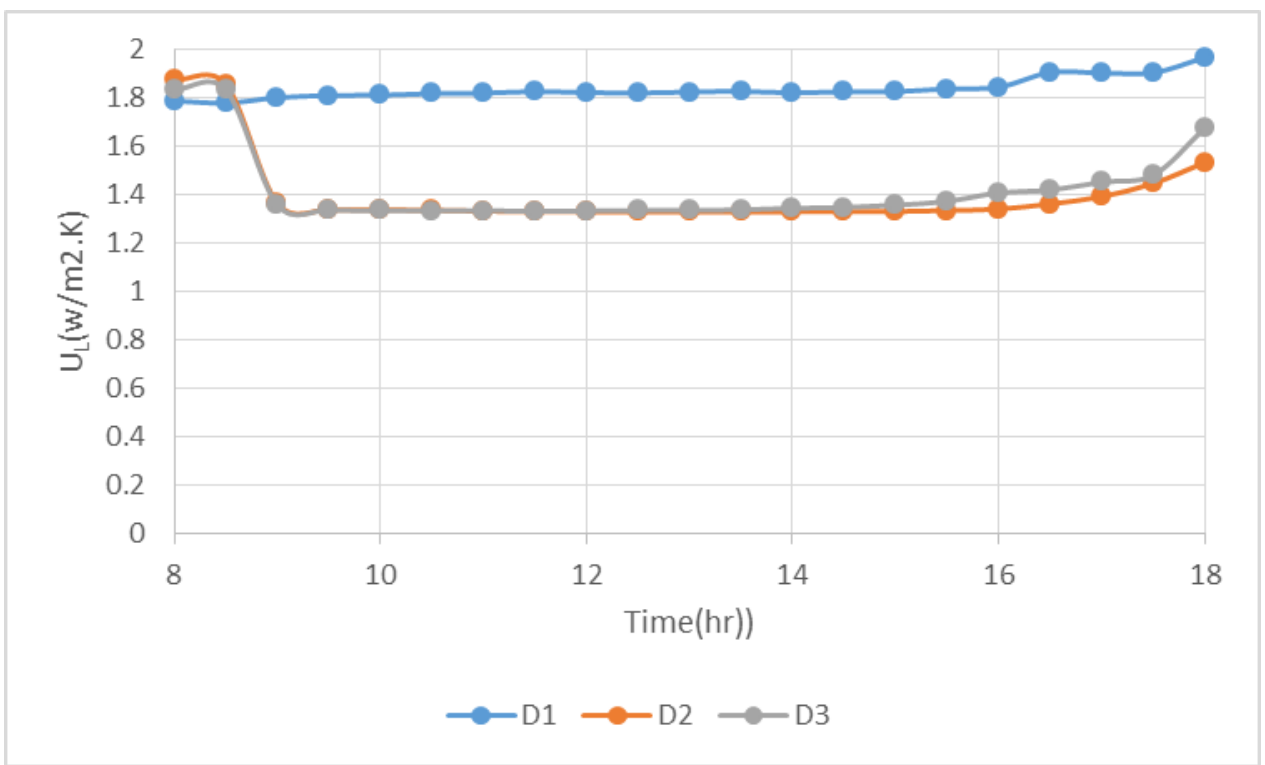

Fig. (9) Variation of overall heat loss coefficient with time in three days in solar collector 
Military Technical College

Kobry El-Kobbah,

Cairo, Egypt

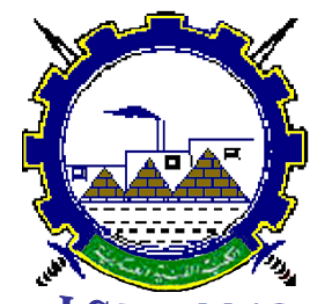

I.C.E.E.2018 $9^{\text {th }}$ International Conference on

Chemical \& Environmental

Engineering

3-5 April 2018

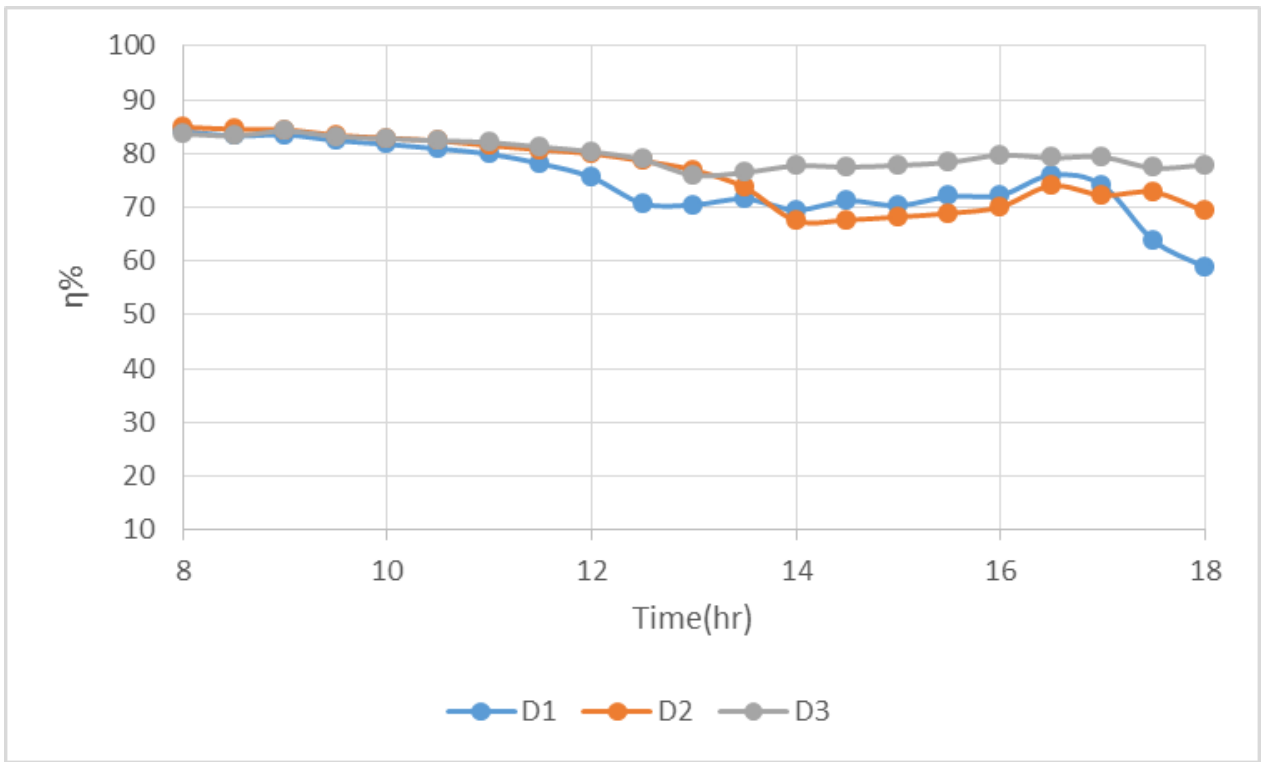

Fig. (10) Variation of energetic efficiency of collector with time in three days for solar collector.

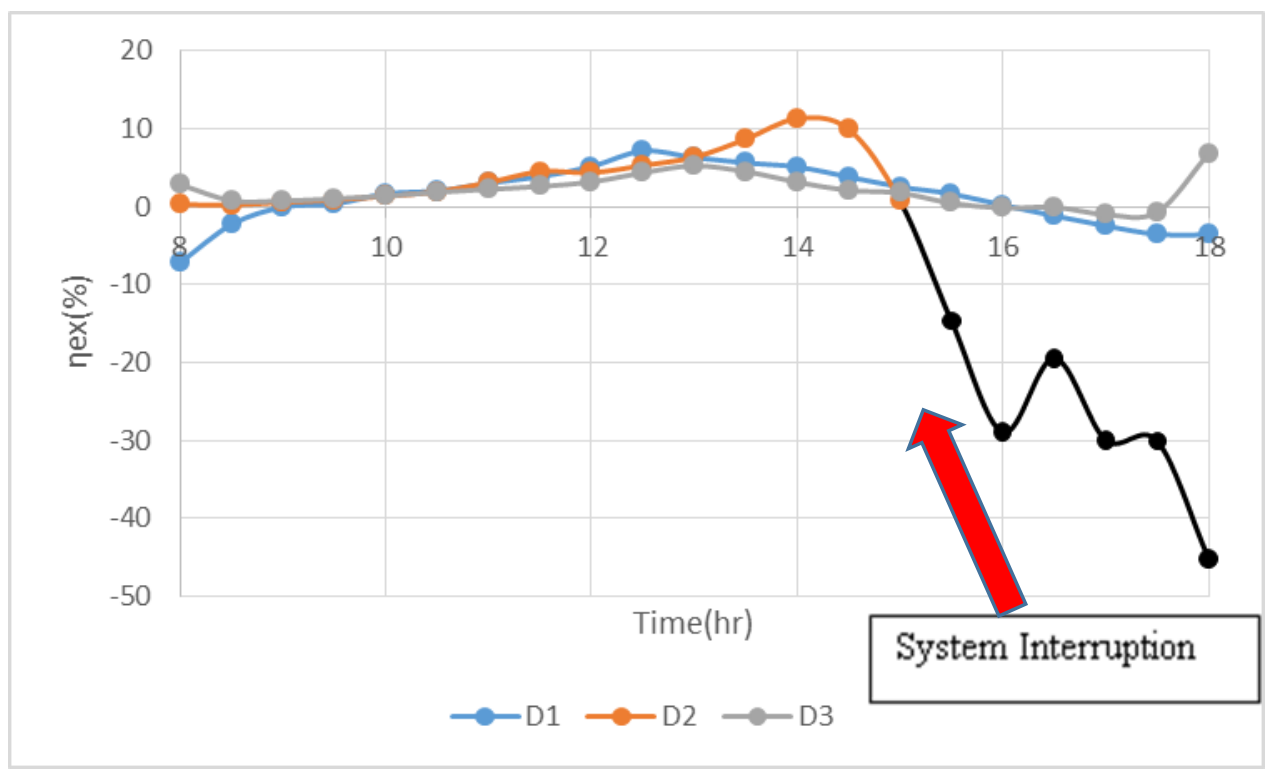

Fig. (11) Variation of exergetic efficiency of collector with time in three days for solar collector. 
Military Technical College

Kobry El-Kobbah,

Cairo, Egypt

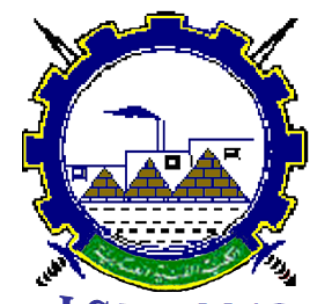

I.C.E.E.2018 $9^{\text {th }}$ International Conference on

Chemical \& Environmental

Engineering

3-5 April 2018

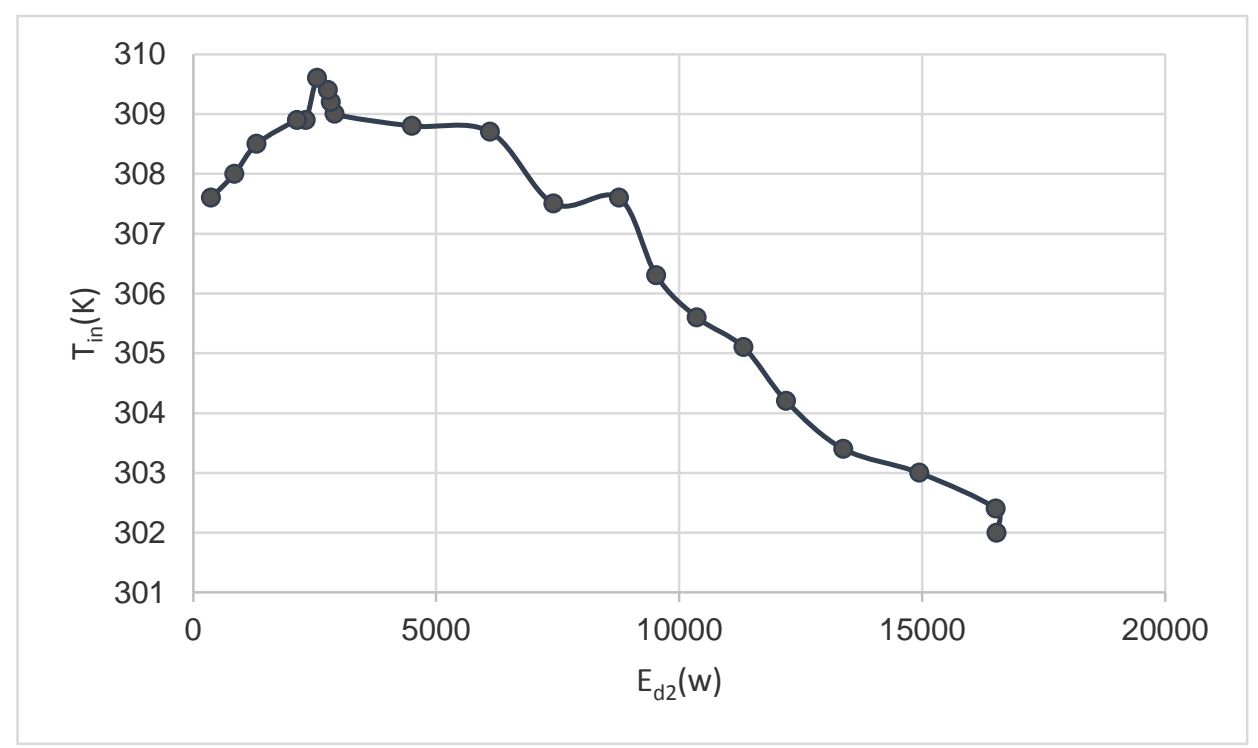

Fig. (12) Effect of inlet saline water temperature with $E_{d 2}$

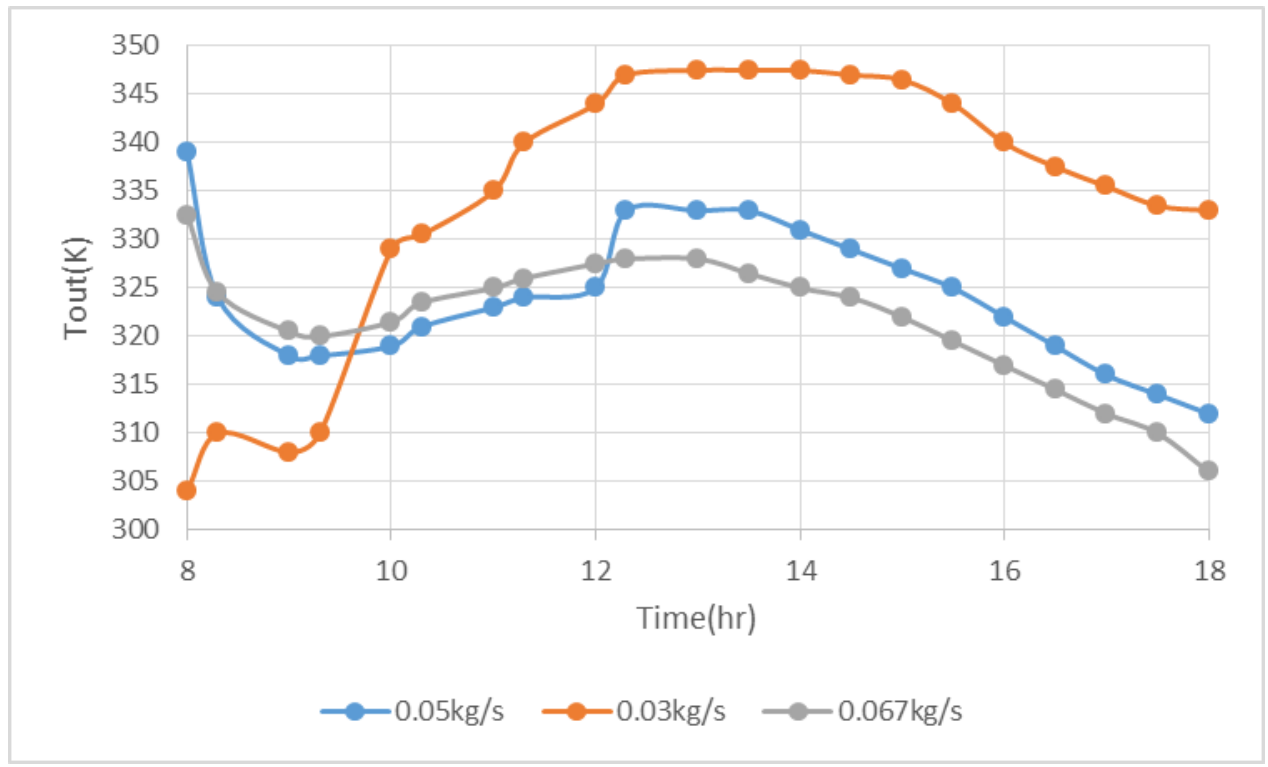

Fig. (13) Variation of outlet saline water temperature with time in three days in heat exchanger. 
Military Technical College Kobry El-Kobbah, Cairo, Egypt

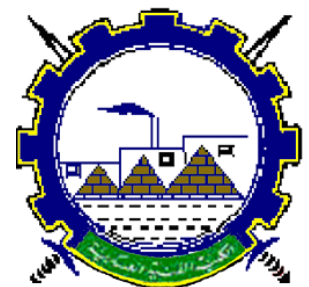

I.C.E.E.2018 $9^{\text {th }}$ International Conference on

Chemical \& Environmental

Engineering

3-5 April 2018

Solar Collector,msaline water $=0.03 \mathrm{~kg} / \mathrm{s}$

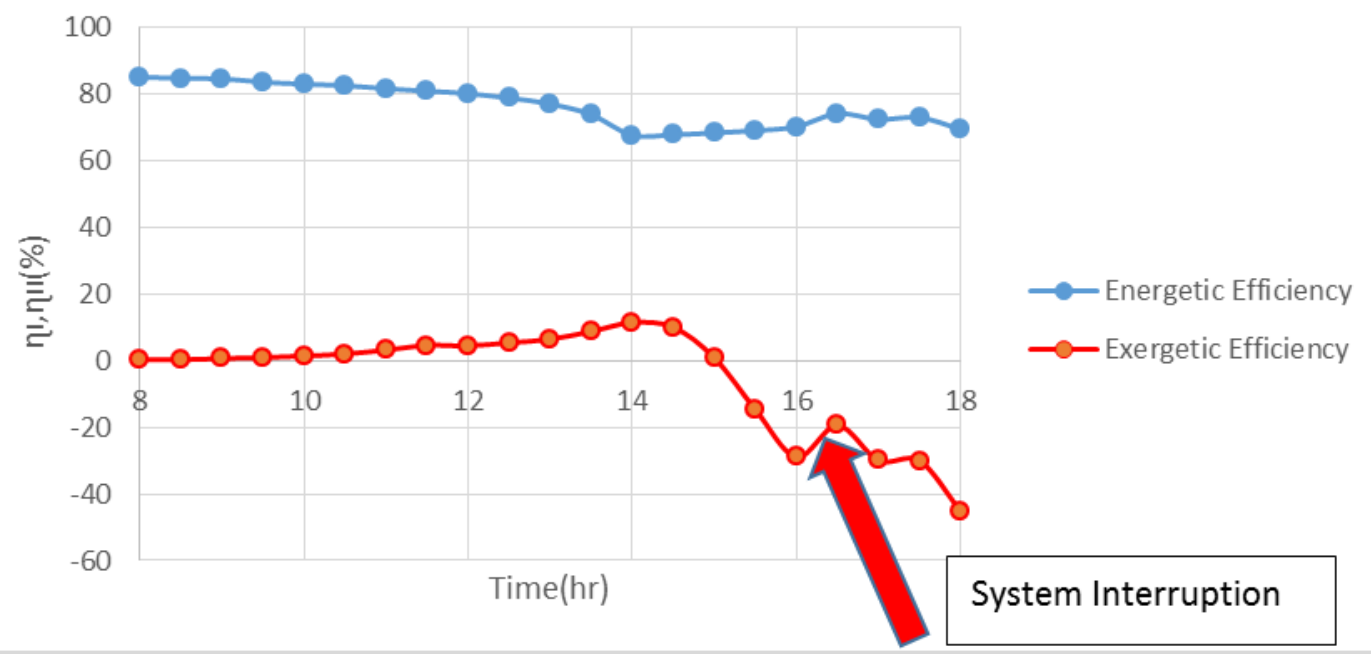

Fig. (14) Comparison between energetic and exergetic efficiency of solar collector in the second day $(0.03 \mathrm{~kg} / \mathrm{s})$

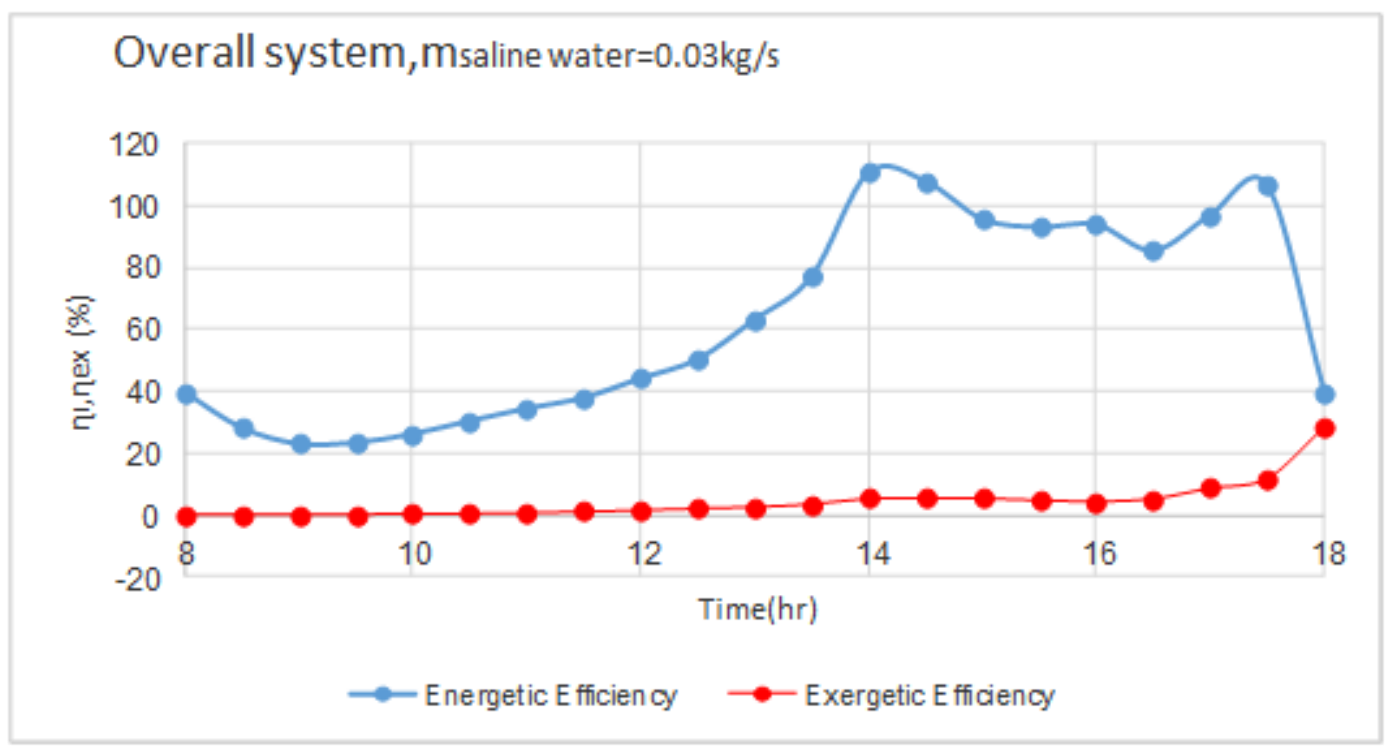

Fig. (15) Comparison between overall Energetic and Exergetic efficiency of solar heating system in the second $\operatorname{day}(0.03 \mathrm{~kg} / \mathrm{s})$. 